\title{
EFEKTIVITAS PENGGUNAAN METODE PROBLEM BASED INTRUCTION (PBI) TERHADAP KETUNTASAN HASIL BELAJAR SISWA
}

\author{
Dessy Anggraini ${ }^{1}$, Novi Prayekti ${ }^{2}$, Feby Indriana Yusuf ${ }^{3}$ \\ Universitas PGRI Banyuwangi \\ e-mail : dessyanggraini1596@gmail.com
}

\begin{abstract}
Abstrak
Penelitian ini merupakan penelitian pendekatan kualitatif dan kuantitatif dengan tujuan mengetahui efektivitas penggunaan metode Problem Based Intruction (PBI) terhadap ketuntasan hasil belajar peserta didik pada materi SPLTV di kelas X. Dengan penggunaan metode Problem Based Intruction (PBI) di harapkan di jadikan inovasi yang baru.

Penentuan responden dilakukan dengan menggunakan purposive sampling. Pengumpulan data dilakukan dengan cara tes, observasi, dan angket. Data yang di peroleh kemudian di analisis secara kualitatif dengan menggunakan persentase.

Hasil penelitian ini menunjukkan bahwa penggunaan metode Problem Based Intruction (PBI) pada materi SPLTV kelas XTKJ di SMK NU Rogojampi dapat di laksanakan dengan baik. Bahwa hasil tes siswa memperoleh persentase sebesar $92 \%$ yang artinya dalam kriteria sangat baik dan hasil observasi siswa memperoleh persentase sebesar $66,75 \%$ yang artinya masuk dalam kriteria baik. Artinya penggunaan metode Problem Based Intruction (PBI) efektif dalam meningkatkan hasil belajar siswa pada materi SPLTV kelas XTKJ di SMK NU Rogojampi.
\end{abstract}

Kata Kunci: Efektivitas, Metode Problem Based Intruction (PBI), Hasil Belajar

\section{PENDAHULUAN}

Pendidikan merupakan faktor utama dalam pembentukan kepribadian manusia.Pendidikan sangat berperan dalam membentuk baik atau buruknya pribadi manusia menurut ukuran normatif (Amalia \& Saukani, 2018:2). Pendidikan adalah proses pembelajaran bagi siswa untuk dapat mengerti, faham, dan membuat siswa lebih kritis dalam berfikir.

Untuk tercapainya tujuan pendidikan maka diperlukan peran pendidik sebagai perantara dalam proses pembelajaran. Guru berperan penting dalam mendidik siswa di sekolah (Putri \& Agustyaningrum, 2015:98). Guru berperan penting dalam mengajarkan berbagai pelajaran. Peran seorang guru bukan hanya mengajar, tetapi guru juga harus mengembangkan kemampuan siswa sehingga siswa dapat memahami 
pelajaran yang disampaikan oleh guru serta manfaatnya dalam kehidupan, salah satunya mata pelajaran matematika.

Salah satu faktor yang berpengaruh dalam hasil belajar siswa dalam pembelajaran yakni model pembelajaran yang dilaksanakan guru. Beberapa guru hanya melaksanakan kegiatan belajar mengajar dengan satu metode yaitu metode ceramah atau tanya jawab (Bahrudin, 2016:199). Salah satu model pembelajaran yang dapat meningkatkan hasil belajar dalam aspek kognitif, minat dan respon siswa dalam menyelesaikan permasalahan kehidupan sehari-hari yaitu model pembelajaran Problem Based Instruction (Septriningsih, dkk, 2017:293).

Istilah Problem Based Instruction rancu dengan Problem Based Learning dan beberapa orang menjadi berbeda pendapat seringkali bahwa Problem Based Instruction dengan Problem Based Learning itu berbeda. Tetapi menurut Khanafiyah \& Yulianti (2012:36) pembelajaran dengan Problem Based Instruction sama dengan pembelajaran Problem Based Learning. Problem Based Learning merupakan suatu pendekatan pembelajaran yang menggunakan masalah dunia nyata sebagai suatu konteks bagi siswa untuk belajar tentang cara berpikir kritis dan ketrampilan pemecahan masalah, serta untuk memperoleh pengetahuan dan konsep yang esensial materi pelajaran (Setyorini, dkk, 2011:55).

Pemahaman siswa pada materi SPLTV yang diajarkan pada kelas X SMK semester ganjil masih tergolong rendah dalam hal menyelesaikan soal. Hal ini diketahui dari pengalaman peneliti saat melakukan PPL di SMK NU Rogojampi. Rendahnya kemampuan pemahaman siswa disebabkan oleh beberapa faktor diantaranya dari guru, siswa, lingkungan, dan metode pembelajaran. Materi SPLTV sebaiknya dipahamkan pada siswa sehingga dapat digunakan dengan baikdi materimateri lain atau mata pelajaran lain.

Hasil wawancara dengan salah satu guru di SMK NU Rogojampi, menunjukkan bahwa menggunakan model konvensional yaitu dengan metode ceramah dan tanya jawab. Pada metode tersebut guru masih menjadi pusat perhatian sedangkan siswa hanya duduk mendengarkan penjelasan dari guru.Hal itu menyebabkan hasil pembelajaran matematika tidak tercapai dengan maksimal. Untuk dapat memperoleh hasil yang maksimal perlu dicobakan metode pembelajaran yang membuat siswa aktif dalam proses pembelajaran, seperti metode Problem Based Instruction. 


\section{METODE PENELITIAN}

Penelitian ini merupakan penelitian dengan metode campuran, yaitu dengan pendekatan kuantitatif dan kualitatif. Pendekatan kuantitatif dipilih karena hasil data yang diperoleh berupa bilangan, sedangkan pendekatan kualitatif dipilih karena hasil yang diperoleh akan dideskriptifkan sesuai dengan indikatorindikator yang telah ditentukan.

\subsection{Instrumen Penelitian}

Instrumen pada penelitian ini adalah lembar observasi aktivitas siswa dan guru, dan tes hasil belajar (pre test dan post test).

\subsection{Teknik Pengumpulan Data}

Teknik pengumpulan data meliputi : observasi (pengamatan), tes hasil belajar (pre test dan post test), dan angket.

\subsection{Teknik Analisis Data}

Analis data tes dilakukan dengan analisis kualitatif dengan cara persentase yang sama. sesuai dengan kkm sekolah yaitu 75 dikatakan tuntas jika siswa $\geq 75$.

\section{HASIL DAN PEMBAHASAN}

\subsection{Analisis Data}

\subsubsection{Analisis Hasil Tes}

Rumus untuk menghitung hasil tes pada pre-tes yang digunakan adalah :

$$
\begin{aligned}
\text { Persentase } & =\frac{\text { Siswa Yang Tuntas }}{\text { Jumlah Siswa }} \times 100 \% \\
& =\frac{12}{25} \times 100 \%=48 \%
\end{aligned}
$$

Rumus untuk menghitung hasil tes pada post-tes yang digunakan adalah :

$$
\begin{aligned}
\text { Persentase } & =\frac{\text { Siswa Yang Tuntas }}{\text { Jumlah Siswa }} \times 100 \% \\
& =\frac{23}{25} \times 100 \%=92 \%
\end{aligned}
$$

Berdasarkan data diatas dapat diketahui bahwa hasil test siswa dari pembelajaran menggunakan metode Problem Based Instruction di kelas XTKJ pada materi SPLTV pada post- $t$ memperoleh persentase sebesar 92\%. Hasil 92\% masuk dalam kriteria sangat baik. 


\subsubsection{Analisis Hasil Observasi}

Rumus untuk menghitung hasil observasi yang digunakan adalah

$$
\begin{aligned}
\text { Persentase } & =\frac{\text { Jumlah Skor }}{\text { Jumlah Aktivitas Siswa }} \times 100 \% \\
& =\frac{534}{8} \times 100 \%=66,75 \% \\
\text { Persentase } & =\frac{\text { Jumlah Skor Tiap Indikator }}{\text { Jumlah Aktivitas Guru }} \times 100 \% \\
& =\frac{31}{11} \times 100 \%=81,8 \%
\end{aligned}
$$

Berdasarkan data diatas dapat diketahui bahwa hasil observasi siswa dari pembelajaran menggunakan metode Problem Based Instruction di kelas XTKJ pada materi SPLTV memperoleh persentase sebesar 66,75\%. Hasil 66,75\% masuk dalam kriteria baik. Dan hasil observasi guru memperoleh persentase $81,8 \%$ masuk dalam kriteria sangat baik.

\subsubsection{Analisis Hasil Angket}

Analisa data hasil angket dilakukan pada repon siswa terhadap metode Problem Based Instruction.

$$
\begin{aligned}
\text { Persentase } & =\frac{\text { Skor Yang Diperoleh }}{\text { Banyaknya Pertanyaan } \times \text { Jumlah Siswa }} \times 100 \% \\
& =\frac{370}{525} \times 100 \%=70,48 \%
\end{aligned}
$$

Berdasarkan data diatas dapat diketahui bahwa hasil angket respon siswa dari pembelajaran yang menggunakan metode problem Problem Based Instruction di kelas XTKJ pada materi SPLTV memperoleh persentase sebesar 70,48\% masuk dalam kriteria baik.

\subsection{Pembahasan}

Berdasarkan hasil observasi siswa dari pembelajaran menggunakan metode Problem Based Instruction di kelas X TKJ pada materi SPLTV diperoleh persentase sebesar $66,75 \%$. Hasil $66,75 \%$ masuk dalam kriteria baik. Hal ini ditunjang dari 8 aktivitas siswa diantaranya aktivitas mendengarkan penyampaian tujuan pembelajaran mencapai 94\%, aktivitas merespon tentang materi SPLTV mencapai $72 \%$, aktivitas mendengarkan dalam bentuk cerita mencapai $100 \%$, aktivitas mendengarkan dan menyimak soal cerita beserta penyelesaiannya mencapai $100 \%$, aktivitas dibimbing oleh guru untuk menyelesaikan soal cerita 
mencapai $94 \%$, aktivitas membuat soal cerita beserta penyelesaiannya mencapai $88 \%$, aktivitas mempersentasikan hasil dari soal cerita dan penyelesaiannya mencapai $96 \%$, serta aktivitas mengevaluasi soal cerita yang sudah dipresentasikan mencapai $69 \%$.

Sedangkan dari hasil observasi guru diperoleh persentase 81,8\%. Hasil observasi termasuk dalam kriteria sangat baik. Hal ini ditunjang dari 11 aktivitas guru yang telah dilakukan dengan 10 aktivitas dilakukan baik dan 1 aktivitas dilakukan cukup, yaitu aktivitas guru mengevaluasi dan menarik kesimpulan dari materi yang telah diajarkan.

Hasil angket respon siswa dari pembelajaran yang menggunakan metode problem Problem Based Instruction di kelas X TKJ pada materi SPLTV diperoleh persentase sebesar 70,48\% termasuk dalam kriteria baik. Hal ini ditunjang dari pertanyaan-pertanyaan respon siswa.Selain hasil observasi dan hasil angket pembelajaran dengan metode pembelajaran Problem Based Instruction diperoleh juga hasil belajar siswa dan dari analisis menggunakan kriteria persentase. Berdasarkan yang diketahui bahwa hasil post-tes siswa dari pembelajaran menggunakan metode Problem Based Instruction di kelas X TKJ pada materi SPLTV memperoleh persentase sebesar 92\%. Hasil 92\% masuk dalam kriteria sangat baik dibandingkan dengan hasil pre-tes siswa hanya memperoleh persentase sebesar $48 \%$ masuk dalam kriteria kurang. Jadi metode pembelajaran Problem Based Instruction dikatakan efektif dalam meningkatkan hasil belajar siswa pada materi SPLTV.

\section{KESIMPULAN DAN SARAN}

Berdasarkan dari hasil penelitian dan analisa data yang telah diuraikan pada bab sebelumnya, dapat diberikan kesimpulan sebagai berikut :

1. Hasil observasi siswa dari pembelajaran menggunakan metode Problem Based Instruction di kelas XTKJ pada materi SPLTV memperoleh persentase sebesar 66,75\%. Hasil 66,75\% masuk dalam kriteria baik. Dan hasil observasi guru memperoleh persentase $81,8 \%$ masuk dalam kriteria sangat baik. 
2. Hasil efektivitas dengan menggunakan analisis tes persentase menunjukkan bahwa hasil post-tes lebih tinggi dari pre-tes dengan menggunakan pembelajaran metode Problem Based Instruction di SMK NU Rogojampi kelas XTKJ pada materi SPLTV diperoleh hasil post-tes persentase sebesar $92 \%$ masuk dalam kriteria sangat baik sedangkan pretes $48 \%$ masuk dalam kriteria kurang. Hasil angket respon siswa dari pembelajaran yang menggunakan metode problem Problem Based Instruction di kelas XTKJ pada materi SPLTV memperoleh persentase sebesar $70,48 \%$ masuk dalam kriteria baik. Jadi metode pembelajaran Problem Based Instruction di katakan efektif dalam meningkatkan hasil belajar siswa pada materi SPLTV.

Berdasarkan hasil analisis data dan kesimpulan yang diperoleh dapat diberikan beberapa saran sebagai perbaikan dimasa yang akan datang, yaitu :

1. Metode Problem Based Instruction dapat digunakan pada materi lainnya.

2. Metode Problem Based Instruction dapat menggunakan LKS atau media lainnya yang berbasis masalah.

3. Metode Problem Based Instruction menjadi siswa lebih aktif dalam proses pembelajaran.

\section{REFERENSI}

Amalia, F., \& Saukani, S. (2018).Efektivitas Model Pembelajaran Problem Based Instruction (PBI) Terhadap Motivasi Belajar dan Hasil Belajar Siswa Pada Mata Pelajaran SKI DI SMP AR-RAHMAN PERCUT.Farina Amalia : Penerapan Model Pembelajaran problem based intruction (PBI), 2.

Anhar, A., \& dkk.(2014). Studi Kelayakan Bahan Ajar Berupa Modul Berbasis Problem Based Instruction (PBI) Pada Pokok Bahasan Kondisi Fisi Wilayah Indonesia Di SMP Kecamatan Pringapus Kabupaten Semarang. Ahmad Anhar / Edu Geography 3 (1) (2014), 12.

Diani, R. (2015). Pengembangan Perangkat Pembelajaran Fisika Berbasis Pendidikan Karakter Dengan Model Problem Based Instruction. 
Pengembangan Perangkat Pembelajaran Fisika Berbasis Pendidikan Karakter Dengan Model Problem Based Instruction, 241-242.

Febrina, T. (2016). Efektivitas Penerapan Model Pembelajaran Problem Based Instruction Terhadap Kemampuan Penalaran Matematika Siswa Kelas VII SMPN 1 Bua. Prosiding Seminar Nasional Volume 03, Nomor 1, 1.

Indrawati, C. (2018). Perbedaan Kemampuan Pemecahan Masalah Matematika Bag Siswa Yang Di Beri Model PBI dan Core Bagi Siswa Kelas VII SMP Negeri 1 Ampel Kabupaten Boyolali. Cici Indarwati/JMP Online Vol. 2 No. 1 Januari (2018) 11-22, 13

Khanafiyah, S., \& Yulianti, D. (2013). Model Problem Based Instruction pada Perkuliahan Fisika Lingkungan untuk Mengembangkan Sikap Kepedulian Lingkungan. Jurnal Pendidikan Fisika Indonesia 9 (2013) 35-42, 36.

Muah, T. (2016). Penggunaan Model Pembelajaran Problem Based Instruction (Pbi) Untuk Meningkatkan Keaktifan Dan Hasil Belajar Matematika Siswa Kelas 9B. Scholaria, Vol. 6, No. 1, Januari 2016: 41 - 53, 44-45..

Pardomuan N. J. M, S. M. (2010). Faktor-Faktor Penentu Keefektifan Pembelajaran Dalam Model Pembelajaran Berdasarkan Masalah (Problem Based Intruction). Generasi Kampus. Volume 1. nomor 2, September , 74.

Savira Putri, I., \& Agustyaningrum, N. (2015). Efektivitas Model Pembelajaran Problem Based Instruction dan Snowball Throwing Ditinjau dari Hasil Belajar Matematika Siswa Kelas VIII SMPN 51 Batam. Jurnal Mercumatika Vol. 1 No. 2 April 2017, 98.

Sony Bahrudin, M. (2014). Upaya Meningkatkan Hasil Belajar Siswa dengan Model Pembelajaran Problem Based Instruction (PBI) pada Pokok Bahasan Perbandingan di Kelas VIII C SMP R. Rahmat Balongbendo Sidoarjo. Journal of Mathematics Education, Science and Technology, 200.

Sugiyono, D. (2016). Metode Penelitian \& Pengembangan Research and Development. Bandung: Alfabeta.

SUGIYONO, P. D. (2017). Metode Penelitian dan Pengembangan (Research and Development $/ R \& D)$. Bandung: 370. 
Surya, Y. F. (2017). Penerapan Model Pembelajaran Problem Based Learning untuk Meningkatkan Hasil Belajar Matematika Siswa Kelas IV SDN 016 Langgini Kabupaten Kampar. Jurnal Pendidikan Matematika, Volume 1, No. 1,42 .

N, H. (2013). Keefektifan Metode Pembelajaran Problem Based Instruction Terhadap Hasil belajar. N Hidayah/Chemistry in Education 3 (1) (2014), 20.

Zuliana, E., Bamoris, S., \& Diyarko. (2016). Matematika Kelompok Teknologi, Kesehatan, dan Pertanian untuk SMK/MAK Kelas X. Jakarta: Erlangga. 